\title{
Parental combining ability as a good predictor of productive crosses in sweet sorghum [Sorghum bicolor (L.) M oench]
}

\author{
R. G. Sandeep, M . R. Gururaja R ao, S. Ramesh*, Chikkalingaiah and H. Shivanna
}

Department of Genetics and Plant Breeding, University of Agricultural Sciences, Bangalore-560065 (Karnataka), INDIA

*Corresponding author. E-mail: ramesh_uasb@ @rediffmail.com

Abstract: The exploitation of heterosis through the development and deployment of hybrids for commercial cultivation is one of the effective approaches for genetic enhancement of crop plants for traits of economic importance. Developing an objective criterion of choosing the parents for developing and testing hybrids is essential for maximizing the success of heterosis breeding. A set of 18 crosses produced from parents differing in their gca effects for bio-energy traits such as millable cane yield, juice volume and juice sugar content (as indicated by Brix $\%$ ) were evaluated in replicated trial in the experimental plots of the Department of Genetics and Plant Breeding, University of Agricultural Sciences, Bangalore during 2006-07. The utility of parental general combining ability for producing high frequency of superior crosses for a set of bio-energy traits in sweet sorghum was investigated. The study suggested that parents with contrasting gca effects produce crosses with higher sca and heterotic potential for the bio-energy traits. The use of female parents with higher gca effects is important for realizing greater probability of crosses with sca effects and heterosis in desirable direction for bio-energy traits.

Keywords: Sweet sorghum, Bio-energy traits, Gca effects, Sca effects, Heterosis

\section{INTRODUCTION}

In India, it is mandatory to market 5 per cent ethanoldoped petrol in nine states and four union territories with plans to increase the doping proportion to 10 per cent in a phased manner by October 2009 (Ramesh and Gowda, 2009). In India. much of the fuel-grade ethanol is being produced from sugarcane molasses (Reddy et al., 2005). The current level of ethanol production in India is just sufficient for 5 per cent blending. Ethanol required for 10 per cent blending cannot be produced from molasses alone (Reddy et al., 2008). Besides these, highly variable supply and cost of molasses, and environmental pollution associated with their use for ethanol production has prompted policy makers, administrators and researchers alike to explore alternative feed stocks for ethanol production (Reddy et al., 2005). Sugarcane juice itself is the potential feed stock for ethanol production. As sugar cane is considered as a food commodity in India besides being water intensive crop, it is not favoured for ethnol production. For drier climates, there is a need to produce bio-energy from more water-use efficient crops, such as sweet sorghum (Sorghum bicolor L. Moench). Sweet sorghum is a very efficient source of bio-energy as it uses $\mathrm{C}_{4}$ photosynthesis pathway to produce sucrose as a storage molecule, which can be directly fermented. Sweet Sorghum is similar to grain sorghum, noted for its high sugar content in the stalk juice. Besides having rapid growth, high sugar accumulation and biomass production potential, sweet sorghum has wider adaptability. The total soluble solids in the juice extracted from stalks of sweet sorghum vary from 16-23 per cent (Reddy et al., 2008).

Use of sweet sorghum does not affect food security as only juice extracted from sugar-rich stalks will be used for ethanol production and grains could be used as food or feed. The stalk juice accumulates maximum sugars when the grains attain physiological maturity (as indicated by blackening of grain hilum). At this stage, the panicles are harvested for separating the grains, which could be used for human consumption or for animal feed. The stalks are harvested for crushing to extract juice from which ethanol will be produced by fermentation (Reddy et al., 2008). The stillage, after extraction of juice from sweet sorghum can be used for co-generation of power. Considering its short duration (about 4 months), limited water requirement $\left(8000 \mathrm{~m}^{3}\right.$ over two crops), which is four times lower than that of sugarcane (12-16 months and $36,000 \mathrm{~m}^{3} \mathrm{crop}^{-1}$, respectively) and dual-purpose nature, there has been increased interest in the utilization of sweet sorghum for ethanol production in India. The use of existing machinery in the sugar factories for ethanol production is the added advantage for this crop (Reddy et al., 2005).

The stalk yield, stalk juice yield and stalk juice sugar content are the key traits that contribute to ethanol yield. The most of the currently used sweet sorghum cultivars were originally bred for fodder purposes. Genetic 
Table 1. Analysis of variance for combining ability and components of genotypic variance for ethanol yield and its attributing traits in sweet sorghum.

\begin{tabular}{|c|c|c|c|c|c|c|}
\hline Source & $\begin{array}{l}\text { Degrees of } \\
\text { freedom }\end{array}$ & $\begin{array}{l}\text { Millable cane } \\
\text { height (cm) }\end{array}$ & $\begin{array}{c}\text { M alleable cane } \\
\text { weight } \\
\left(\text { g plant }^{-1}\right) \\
\end{array}$ & $\begin{array}{l}\text { J uice volume } \\
\left.\text { (ml plant }^{-1}\right)\end{array}$ & Brix (\%) & $\begin{array}{l}\text { Ethanol yield } \\
\left(\mathrm{ml} \mathrm{plant}^{-1}\right)\end{array}$ \\
\hline Replication & 1 & 0.27 & 29.93 & 2.45 & 0.88 & 0.06 \\
\hline Parents $(\mathrm{L}+\mathrm{T})$ & 8 & $3628.49 * *$ & $14432.10^{* *}$ & $1280.07 * *$ & 4.36 & $6.58 * *$ \\
\hline Lines (L) & 2 & 627.63 & 296.00 & 81.38 & 3.82 & 1.72 \\
\hline Testers (T) & 5 & 3023.29 & 11049.48 & 618.32 & 5.45 & 4.84 \\
\hline$L \times T$ & 10 & $12656.25^{* *}$ & $59617.36^{* *}$ & $6986.17 * *$ & 0.01 & $25.03 * *$ \\
\hline Crosses & 17 & $2566.07 * *$ & $29355.35 * *$ & $2047.05^{* *}$ & $14.03 * *$ & $21.54 * *$ \\
\hline Par ents vs crosses & 1 & $3652.29 * *$ & $28910.08 * *$ & $797.61 * *$ & $9.61^{*}$ & 0.72 \\
\hline Error & 26 & 22.65 & 92.33 & 18.58 & 1.88 & 0.2 \\
\hline$\sigma_{\text {gca }}^{2}$ & & 36.87 & 278.52 & 43.09 & 0.23 & 0.50 \\
\hline$\sigma_{\text {sca }}^{2}$ & & 864.56 & 11547.34 & 423.83 & 3.52 & 4.97 \\
\hline$\sigma_{A}^{2}$ & & 73.74 & 557.04 & 106.18 & 0.46 & 1.02 \\
\hline$\sigma_{D}^{2}$ & & 864.56 & 11547.34 & 423.83 & 3.52 & 4.97 \\
\hline
\end{tabular}

* Significant at $\mathrm{P}=0.05, * *$ Significant at $\mathrm{P}=0.01$

improvement for traits contributing to ethanol yield requires adoption of a suitable selection strategy that hinges on the sound knowledge about the nature of genetic control of economic traits (among others) in the working germplasm collection. Hybridization-driven variability followed by pedigree selection is the major approach adopted in the development of pure-line cultivars for use as end-products and/or in the development of inbred lines for use in hybrid cultivars. Very often, a plant breeder/researcher is confronted with the task of handling segregating populations derived from a large number of crosses. Early elimination of poor crosses helps in efficient utilization of land, time and human resources and allows handling of a reasonably large segregating populations derived from a few promising crosses. Also, development of an objective method of producing a very high frequency of superior crosses help save substantial resources and improve the pace and efficiency of sweet sorghum genetic improvement. It therefore becomes imperative to design an objective method of selecting parents for producing crosses that are likely to result in higher frequency of superior lines and/or superior parents for developing hybrids for commercial cultivation after extensive testing. As a result, selection of parents is the key to success in crop improvement.

Under this premise, an investigation was carried out to assess the utility of parental general combining ability effects (gca) for making crosses that are likely to result in higher frequency of superior lines.

\section{MATERIALS AND METHODS}

The material for the study consisted of nine elite genotypes viz., ICSV 93046, RSSV 9, RSSV 56, ICSV 700,
NSSV 254, SSV 84, ICSR 93034, RSSV 104 and RSSV 76. These were specifically bred for higher millable cane yield, stalk juice yield and stalk juice sugar content. The seeds of these varieties were procured from National Research Center for Sorghum (NRCS), Hyderabad, India. The genotypes, ICSV 93046, RSSV 9, RSSV 56, ICSV 700, NSSV 254 and SSV 84 were used as male parents (testers) and other three genotypes, ICSR 93034, RSSV 104 and RSSV 76 were used as female parents (lines), which were crossed in Line $\times$ Tester mating design by hand emasculation and pollination during 2006-2007 rainy season in the experimental plots of the Department of Genetics and Plant Breeding (GPB), University of Agricultural Sciences (UAS), Bangalore, India. The seeds of 18 hybrids were sown in Randomized Complete Block Design (RCBD) with two replications during 2006-2007 post rainy season. The parents were sown in RCBD with two replications in contiguous plot in the same season. The parents and hybrids were grown in two rows plots of $3 \mathrm{~m}$ long at spacing of $0.60 \mathrm{~m}$ between the rows. The seedlings were thinned 15 days after sowing to maintain a spacing of $0.30 \mathrm{~m}$ between plants within a row. The crop was provided protective irrigation once in 15 days throughout the crop growth period. All the recommended crop production and protection practices were followed to raise a good and healthy crop.

Data recording: In each hybrid and parent, ten competitive plants were randomly selected for recording data on millable cane height and millable cane weight. The height of the sample plants from the soil surface to uppermost node was measured and expressed as average millable cane height $(\mathrm{cm})$. The stalks from base of the sample plants to uppermost node was harvested, weighed 
and recorded as average millable cane weight $\left(\mathrm{g} \mathrm{plant}^{-1}\right)$. Harvested stalks of sample plants were crushed using a sugarcane crusher to extract juice. The volume of the juice was measured using a measuring cylinder and expressed in ml plant $^{-1}$. Juice extracted from sample plants was mixed thoroughly and sugar content in composite juice was measured by refractometer as Brix (\%).

Estimation of ethanol yield: From the total juice extracted, $250 \mathrm{ml}$ of juice was kept for fermentation in $500 \mathrm{ml}$ conical flask by adding $1 \mathrm{~g}$ of bakers' yeast (Saccharomyces cerevisiae) and the juice was kept in semi anaerobic condition for a week and the fermented juice was subjected to distillation at $85^{\circ} \mathrm{C}$ temperature using single distillation unit. Ethanol was collected and measured as ml plant ${ }^{-1}$.

Statistical analysis: Replication-wise mean values of data recorded on sample plants in $F_{1}$ crosses and their parents were subjected to statistical analysis. The total variability of crosses was partitioned into different sources such as lines, testers, lines $\times$ testers interaction and lines vs testers using analysis of variance (ANOVA) for combining ability (Arunachalam, 1974). The gca effects of parents and specific combining ability (sca) effects of crosses for millable cane height, millable cane weight, stalk juice volume, Juice Brix (\%) and ethanol yield $\left(\mathrm{ml} \mathrm{plant}^{-1}\right)$ were estimated (Kempthorne, 1957). Heterosis of crosses over mid-parental value was estimated. The significance of parental gca effects and sca effects and mid-parent heterosis was tested using Students' ' $t$ ' test by comparing computed test statistic ' $t$ ' value with that of table ' $t$ ' value at error degrees of freedom (Snedecor and Cochran, 1994).

O ver all status of parents based on gca effects: The gca effects vary with the traits both in magnitude and direction. Therefore, plant breeder/researcher is confronted with a problem of making a decision as to which of the parents are desirable general combiners over a set of traits under investigation. An objective method of determining the status of parent with respect to its gca effects over a set of traits (Arunachalam and Bondopadhyay, 1979) was used in the present study. The average gca effects of lines and tester for a particular trait was used as a norm to score the parents. The parents with a significant gca effects more than the norm for a trait was assigned +1 score and those with significant gca effects less than the norm for a trait was assigned 1 score. The parents with non-significant gca effects was assigned zero score. This procedure was repeated for all the traits. The scores of each parent were summed over all the traits to arrive at a total score. The total scores of all the parents were averaged to arrive at a final norm. The final norm was used as a criterion to designate status of each parent with respect to its gca effects. The parents whose total score was higher than the final norm was
Table 2. Overall general combining ability status of sweet sorghum parents.

\begin{tabular}{lcc}
\hline Lines & Total Score & Overall Status \\
\hline ICSR 93034 & 10.0 & $\mathrm{~L}$ \\
RSSV 104 & 20.0 & $\mathrm{H}$ \\
RSSV 76 & 18.0 & $\mathrm{H}$ \\
\hline & \multicolumn{2}{c}{ Final Score = 16 } \\
\hline Testers & Total Score & Overall Status \\
\hline ICSV 93046 & 38.0 & $\mathrm{H}$ \\
RSSV 9 & 16.0 & $\mathrm{~L}$ \\
RSSV 56 & 19.0 & $\mathrm{~L}$ \\
ICSV 700 & 32.0 & $\mathrm{H}$ \\
NSSV 254 & 24.0 & $\mathrm{~L}$ \\
SSV 84 & 18.0 & $\mathrm{~L}$ \\
\hline & \multicolumn{3}{c}{ Final Score $=24.5$} \\
\hline
\end{tabular}

$\mathrm{H}=$ Overall high gca status, $\mathrm{L}=$ Overall low gca status

assigned overall high $(\mathrm{H})$ gca status while those whose total score was lower than the final norm was assigned overall low (L) gca status. Based on the overall gca status of parents, the crosses were grouped into $\mathrm{H} \times \mathrm{H}, \mathrm{H} \times \mathrm{L}, \mathrm{L}$ $\times \mathrm{H}$ and $\mathrm{L} \times \mathrm{L}$ categories. The number of crosses belonging to each of these four classes was counted. Among these, the number of crosses with overall high sca status and those with high overall mid-parent heterosis were counted in each cross category. As the number of crosses belonging to each of four cross category differed, conditional probability of a given cross with overall high sca and heterotic status belongs to a particular cross category was estimated as the ratio of number of crosses with overall high sca and heterotic status in each cross category to the total number of crosses with overall high sca and heterotic status (Arunachalam and Bandyopadhyay, 1979).

\section{RESULTS AND DISCUSSION}

A nalysis of variation: Analysis of variance for combining ability (Table 1) indicated presence of considerable variability among the crosses for all the traits despite lack of differences either among the lines per se or testers per se. The dispersion of positive and negative alleles controlling the trait variation could be attributed to absence of significant differences among lines and testers. The presence of all positive alleles in heterozygous condition with dominance of the former (as could be inferred from significant mean squares due to lines $x$ testers interaction) in the crosses seems to be cause for significant variation among the crosses while parents themselves not significantly different from each other. The enhanced expression of the crosses as a group compared to their parents as another group has reflected in significant mean squares due to parents' vs crosses. It therefore appears that unpredictable component (lines $x$ testers' interaction) rather than the main effect of lines and testers per se contribute to overall variation among the crosses for all the traits. 
Table 3. Overall specific combining ability status of sweet sorghum hybrids.

\begin{tabular}{lcccccc}
\hline \multirow{2}{*}{ Testers Lines } & \multicolumn{2}{c}{ C SR 93034(L) } & \multicolumn{2}{c}{ RSSV 104 (H) } & \multicolumn{2}{c}{ RSSV 76 (H) } \\
\cline { 2 - 7 } & $\begin{array}{c}\text { Total } \\
\text { Score }\end{array}$ & $\begin{array}{c}\text { Overall } \\
\text { Status }\end{array}$ & $\begin{array}{c}\text { Total } \\
\text { Score }\end{array}$ & $\begin{array}{c}\text { Overall } \\
\text { Status }\end{array}$ & $\begin{array}{c}\text { Total } \\
\text { Score }\end{array}$ & $\begin{array}{c}\text { Overall } \\
\text { Status }\end{array}$ \\
\hline ICSV 93046 (H) & 79 & $\mathrm{H}$ & 34 & $\mathrm{~L}$ & 93 & $\mathrm{H}$ \\
RSSV 9 (L) & 91 & $\mathrm{H}$ & 34 & $\mathrm{~L}$ & 68 & $\mathrm{H}$ \\
RSSV 56(L) & 85 & $\mathrm{H}$ & 66 & $\mathrm{~L}$ & 48 & $\mathrm{~L}$ \\
ICSV 700 (H) & 70 & $\mathrm{H}$ & 104 & $\mathrm{H}$ & 25 & $\mathrm{~L}$ \\
NSSV 254 (L) & 24 & $\mathrm{~L}$ & 91 & $\mathrm{H}$ & 93 & $\mathrm{H}$ \\
SSV 84 (L) & 54 & $\mathrm{~L}$ & 61 & $\mathrm{~L}$ & 77 & $\mathrm{H}$ \\
\hline
\end{tabular}

$\mathrm{H}=$ Overall high gca status of parents/sca status of crosses; $\mathrm{L}=$ Overall low gca status of parents /sca status of crosses

The predominance of significant variation due to lines $x$ testers is further supported by higher magnitude of sca variances (attributed to non-additive genetic variance) compared to gca variances (attributed to additive genetic variance) and also from the ratio of sca variance and gca variance for almost all the traits. These findings are similar to those reported by Sankarapandian et al. (1994) for millable cane height, juice Brix, millable stalk yield and juice yield, by Premalatha et al. (2006) for millable cane height, and juice Brix and by Kadam et al. (2000) for millable cane height. Thus non-additive genetic variance seems to be the major cause for variation in traits related to ethanol yield and thus justifying exploitation of heterosis in genetic improvement of sweet sorghum.

O ver all gca status of lines and testers: The estimates of gca effects of lines and testers varied significantly for each trait (results not shown). No single line or a tester was a good general combiner for all the traits. The use of an objective method as described in material and methods section revealed that the lines such as RSSV 104 and RSSV 76 and testers such as ICSV 93046 and ICSV 700 were high general combiners for the set of traits considered (Table 2). These lines and testers appear to transmit genes with additive effects to their progeny for all the traits. The involvement of these genotypes in recombination breeding is likely to result in superior progenies, which provides raw material for selection of superior lines with a combination of higher cane yield, stalk juice yield and stalk juice sugar content.

O verall sca status of cr osses: As is true for gca effects, no hybrid was found to be the best specific combination for all the traits (data not shown). The differential magnitude and direction of correlation coefficients among the set of traits considered for the study could be attributed to differences in gca effects between traits (Arunachalam and Bandyopadhyay, 1980). Also, the performances of crosses are not predictable as dominance gene action predominated the inheritance of all the traits. The crosses such as ICSR $93034 \times$ ICSV 93046, ICSR $93034 \times$ RSSV 9, ICSR $93034 \times$ RSSV 56, ICSR $93034 \times$ ICSV 700, RSSV $104 \times$ ICSV 700, RSSV $104 \times$ NSSV 254, RSSV $76 \times$ ICSV 93046, RSSV $76 \times$ RSSV 9 , RSSV $76 \times$ NSSV 254 , RSSV $76 \times$ SSV 84 were found to have overall high sca status across the traits considered for the study (Table 3). Most of these crosses involved at least one of the parents with overall high gca status. Over all heter otic status of cr osses: Mid parent heterosis of majority of the crosses was significant for all the traits except Brix per cent (data not shown). As is true for parental gca effects, and sca effects of crosses, no single cross was found to be the best heterotic cross combination for all the traits. Based on the criteria as explained in the material and methods section, nine crosses such as ICSV $93046 \times$ ICSR 93034, ICSV 93046× RSSV 104, ICSV $93046 \times$ RSSV 76, RSSV $56 \times$ RSSV 104, ICSV $700 \times$ ICSR 93034, ICSV $700 \times$ RSSV 104, NSSV 254 $\times$ RSSV 104 , NSSV $254 \times$ RSSV 76 and SSV $84 \times$ RSSV 76 were found to be overall high heterotic status across the traits. All these crosses involved at least one of the parents with overall high gca status (Table 4).

Relationship of parental gca status with over all sca and heter otic status of crosses: The number of crosses in

Table 4. Overall heterotic status of sweet sorghum hybrids.

\begin{tabular}{lcccccc}
\hline & \multicolumn{2}{c}{ ICSR $93034(\mathrm{~L})$} & \multicolumn{2}{c}{ RSSV 104 $(\mathrm{H})$} & \multicolumn{2}{c}{ RSSV 76 (H) } \\
\cline { 2 - 7 } & $\begin{array}{c}\text { Total } \\
\text { Score }\end{array}$ & $\begin{array}{c}\text { Overall } \\
\text { Status }\end{array}$ & $\begin{array}{c}\text { Total } \\
\text { Score }\end{array}$ & $\begin{array}{c}\text { Overall } \\
\text { Status }\end{array}$ & $\begin{array}{c}\text { Total } \\
\text { Score }\end{array}$ & $\begin{array}{c}\text { Overall } \\
\text { Status }\end{array}$ \\
\hline ICSV 93046 (H) & 81.0 & $\mathrm{H}$ & 78.0 & $\mathrm{H}$ & 100.0 & $\mathrm{H}$ \\
RSSV 9 (L) & 45.0 & $\mathrm{~L}$ & 34.0 & $\mathrm{~L}$ & 48.0 & $\mathrm{~L}$ \\
RSSV 56 (L) & 51.0 & $\mathrm{~L}$ & 74.5 & $\mathrm{H}$ & 52.0 & $\mathrm{~L}$ \\
ICSV 700 (H) & 67.0 & $\mathrm{H}$ & 102.0 & $\mathrm{H}$ & 62.0 & $\mathrm{~L}$ \\
NSSV 254 (L) & 29.5 & $\mathrm{~L}$ & 99.0 & $\mathrm{H}$ & 107.0 & $\mathrm{H}$ \\
SSV 84 (L) & 36.0 & $\mathrm{~L}$ & 61.0 & $\mathrm{~L}$ & 73.0 & $\mathrm{H}$ \\
\hline
\end{tabular}

$\mathrm{H}=$ Overall high gca status of parents / heterotic status of crosses; L = Overall low gca status of parents / heterotic status of crosses 
Table 5. Relationship of parental gca status with overall sca and heterotic status of sweet sorghum crosses.

\begin{tabular}{cccccc}
\hline $\begin{array}{c}\text { Category of crosses } \\
\text { based on their } \\
\text { parental gca status }\end{array}$ & $\begin{array}{c}\text { No. of crosses } \\
\text { under the } \\
\text { category }\end{array}$ & $\begin{array}{c}\text { No. of crosses } \\
\text { with high overall } \\
\text { sca status }\end{array}$ & $\begin{array}{c}\text { No. of crosses } \\
\text { with high } \\
\text { overall } \\
\text { heter otic status }\end{array}$ & $\begin{array}{c}\text { Conditional probability } \\
\text { of a given cross with high } \\
\text { sca status belongs to the } \\
\text { category }\end{array}$ & $\begin{array}{c}\text { Conditional } \\
\text { probability of a } \\
\text { given cr oss with } \\
\text { high heter otic } \\
\text { status belongs to the } \\
\text { category }\end{array}$ \\
\hline $\mathrm{H} \times \mathrm{H}$ & 04 & 02 & 03 & 0.20 & 0.33 \\
$\mathrm{H} \times \mathrm{L}$ & 08 & 04 & 04 & 0.40 & 0.44 \\
$\mathrm{~L} \times \mathrm{H}$ & 02 & 02 & 02 & 0.20 & 0.22 \\
$\mathrm{~L} \times \mathrm{L}$ & 04 & 02 & 00 & 0.20 & 0.00 \\
\hline
\end{tabular}

H: Overall high gca status of parents; L: Overall low gca status of parents

each cross category $(\mathrm{H} \times \mathrm{H}, \mathrm{H} \times \mathrm{L}, \mathrm{L} \times \mathrm{H}, \mathrm{L} \times \mathrm{L})$ varied.

Given a cross with overall high sca and heterotic status, the probability that the cross belongs to $\mathrm{H} \times \mathrm{L}$ category was highest (Table 5). The conditional probability of a cross with overall high sca and heterotic status belongs to $\mathrm{H} \times \mathrm{H}$ and $\mathrm{L} \times \mathrm{H}$ cross categories were comparable. These results indicate the necessity of parental diversity in terms of gca status for realizing higher frequency of crosses with high overall sca and heterotic status. Apart from choosing parents with contrasting gca status, choice of seed parents appears to be most crucial for the occurrence of crosses with overall high sca and hetersis status, as indicated by significantly higher conditional probability of heterotic crosses belong to $\mathrm{H} \times \mathrm{L}$ cross category compared to other cross categories. The unique superiority of $\mathrm{H} \times \mathrm{L}$ crosses has also been reported through studies of similar nature by Arunachalam and Bandyopadhyay (1980) in Brassica campestris, Reddy and Arunachalam (1980) in pearl millet, Lokaprakash et al. (1995) in rice, Ramesh et al. (1998) and Lalitha Reddy et al. (2000) in sesame, Joshi et al. (1997) and Mohan Rao et al. (2004) in sunflower. The theoretical investigation by Cress (1966) as elaborated by Mather and Jinks (1982) and Falconer and Mackay (1996) clearly indicate the requirement of directional dominance and a wide parental gene frequency for the traits under study for harnessing higher heterosis. These theoretical investigations adequately support the unique superiority of $\mathrm{H} \times \mathrm{L}$ crosses in the present study which could be due to substantial parental difference in the frequency of additive genes with positive effects. The utility of heterotic crosses resulting from divergent genotypes has been amply demonstrated in grain sorghum and finger millet. By utilizing exotic (and temperate) $\times$ Indian (and tropical) and dwarf $\times$ tall crosses, several grain sorghum varieties and hybrids were developed (Rao, 1972; Rao and Rana, 1982). Several high yielding finger millet varieties (Indaf 1, 3, 5, 6, 7, 8, 9, 10, 11 and 15 and MR 1) were developed from the segregating generations derived from the crosses between germplasm accessions originating from India and Africa (Ravishankar et al., 2004).

\section{Conclusion}

The results indicated that parents with contrasting gca effects produce crosses with higher sca effects and heterotic potential for millable cane yield and sugar-rich juice yield, the components of ethanol yield. The study also suggested that apart from parental gca diversity, use of seed parent with higher gca effects is important for realizing higher probability of crosses with high overall sca and heterotic status for components of ethanol yield. It is worth making $\mathrm{H} \times \mathrm{L}$ crosses followed by $\mathrm{L} \times \mathrm{H}$ and $\mathrm{H} \times \mathrm{H}$ crosses for realizing high frequency of heterotic hybrids. Adoption of such a strategy has bearing on optimizing resources for rapid sweet sorghum genetic improvement.

\section{ACK NOW LEDGEMENTS}

The authors are grateful to Dr. N. Seetharama, Director and Dr. S. S. Rao, Senior Scientist and Principal Investigator (Physiology and Sweet Sorghum), NRCS, Hyderabad for supply of sweet sorghum germplasm seeds for the study.

\section{REFERENCES}

Arunachalam. V. (1974). Fallacy behind the use of modified line $\times$ tester design. Indian J ournal of $G$ enetics and Plant Breeding, 34: 280-287.

Arunachalam, V. and Bandyopadhyay, A. (1979). Are "Multiple cross- Multiple pollen hybrids" an answer for productive populations in Brassica compestris var. brown sarson?. Theor etical and Applied G enetics, 54: 203-207.

Arunachalam, V. and Bandyopadhyay, A. (1980). Are "Multiple cross- Multiple pollen hybrids" an answer for productive populations in Brassica compestris var. brown sarson? Part 2: Evaluation of Mucromps. Theoretical and Applied G enetics,58: 5-10.

Cress, C. E. (1966). Heterosis of hybrid related to gene frequencies between the populations. Genetics, 53:269-274.

Falconer, D. S. and Mackay, T. F. C. (1996). Introduction to Quantitative Genetics (pp 255-256). England: Addison Wesley Longman Limited.

Joshi, S. S., Ramesh, S., Gangappa, E., Jagannath, D. P. and Chikkalingiah (1997). Limits to parental divergence for the occurrence of heterosis in sunflower (Helinathus annuus L.). Helia, 20: 95-100.

Kadam, D. E., Patel, F. B., Bhor, T. J. and Harer, P. N. (2000). 
Line $x$ tester analysis in sweet sorghum hybrids. J ournal of Maharashtra Agricultural U niversities, 25:318-319.

Kempthorne, O. (1957). An introduction to genetic statistics (pp 458-471). New York, USA: John Wiley and Sons.

Lalitha Reddy, S. S., Sheriff, R. A., Ramesh, S. and Mohan Rao, A. (2000). Exploring possible limits to parental divergence for the occurrence of heterosis in sesame (Sesamum indicum L.). C rop Research, 19:305-309.

Lokaprakash, R., Shivashankar, G., Mahadevappa, M., Shankare Gowda, B. T., Kulkarni, R. S. and Shashidhar, H. E. (1995). Heterosis and combining ability across traits in selected lines of rice. Mysore J ournal of Agricultural Sciences, 29: 204-207.

Mather, K. and Jinks, J. L. (1982). Biometrical Genetics (pp 125-131). London: Chapmam and Hall.

Mohan Rao, A., Lakshmikanth Reddy., Kulkarni, R. S., Ramesh, S. and Lalitha Reddy, S. S. (2004). Prediction of heterosis based on genetic divergence of parents through regression analysis in sunflower. Helia, 27: 51-58.

Premalatha, N., Kumaravadivel, N. and Veerabadhiran, P. (2006). Heterosis and combining ability for grain yield and its components in sorghum [Sorghum bicolor (L.) Moench]. Indian J ournal of $G$ enetics and Plant Breeding, 66: 123126.

Ramesh, S. and Balakrishna Gowda. (2009). Feed stock, crop research and development for bio-energy production in India J ournal of Applied and Natural Science, 1: 109- 116.

Ramesh, S., Sheriff, R. A., Mohan Rao, A. and Gangappa, E. (1998). Combining ability in sesame (Sesamum indicum L.). Crop Research, 15:238-244.

Rao, N. G. P. (1972). Sorghum breeding in India: Recent developments. Pages 101-142. In: Sorghum in seventies (Rao NGP and House LR eds). New Delhi, India: Oxford and IBH Publishing Co.

Rao, N. G. P. and Rana, B. S. (1982). Selection in temperate tropical crosses of sorghum. Pages 403-420 in sorghum in eighties, Proceedings of international symposium on sorghum, 2-7, November 1981, ICRISAT, Patancheru, Andhra Pradesh, India.

Ravishankar, C. R., Ramappa, H. K. and Prakash, P. (2004). Ragi Research at Mandya. Zonal Agricultural Research Station (ZARS), VC Farm, Mandya - 571405. University of Agricultural Sciences, GKVK, Bangalore - 560 065, pp 12-14.

Reddy, B. B. and Arunachalam, V. (1980). Evaluation of heterosis through combining ability in pearl millet. I. Single crosses. Indian J ournal of $\mathrm{G}$ enetics and Plant B reeding, 41 : 59-65.

Reddy, B. V. S., Ramesh, S., Sanjana Reddy, P., Ramaiah, B., Salimath, P. M. and Rajashekar Kachapur. (2005). Sweet sorghum-a potential alternative raw material for bio-ethanol and bio-energy. International Sorghum and Millets N ewsl etter, 46: 79-86.

Reddy, B. V. S., Ramesh, S., Ashok Kumar, A., Wani, S. P., Ortiz, R., Ceballos, H. and Sreedevi, T. K. (2008). Bio-fuel crops research for energy security and rural developing countries. Bio-energy Research, 1: 248-258.

Sankarapandian, R., Ramalingam, J., Pillai, M. A. and Vanniarajan, C. (1994). Heterosis and combining ability studies for juice yield related characteristics in sweet sorghum. Annals of Agricultural Research, 15:199-204.

Snedecor, G W. and Cochran, W. G (1994). Statistical M ethods (pp 46). Ames, Iowa, USA: Iowa State University Press. 